\title{
Switchgrass growth and development: Water, nitrogen, and plant density effects
}

\author{
M. A. SANDERSON AND R. L. REED
}

Authors are research agronomist, USDA-ARS Pasture Systems and Watershed Management Research Laboratory, Curtin Road, University Park, Penn. 16802-3702 and forage specialist, The Samuel Roberts Noble Foundation, Box 2180, Ardmore, Okla. 73402. At the time of the research the authors were associate professor and research associate, Texas A\&M University Agricultural Research and Extension Center, Stephenville, Tex.

\begin{abstract}
Switchgrass (Panicum virgatum L.), an important component of the tallgrass prairie, is a productive warm-season forage grass. Interest in growing switchgrass for alternative uses has raised questions about resource use during production. The objective of our study was to examine how resource inputs affected interspecific plant competition in switchgrass. 'Alamo' switchgrass was established from seed in outdoor lysimeters in May 1993 and grown under 22 or $112 \mathrm{~kg} \mathrm{~N} \mathrm{ha}^{-1}$, and under field capacity or water-deficit conditions until August 1994. Plant spacing varied systematically from 10 to $70 \mathrm{~cm}$. Plants were harvested in late summer each year and individual plant dry weight, tiller number, leaf area, and morphological development stage were measured. Soil moisture tensions below $\mathbf{- 4 5} \mathrm{kPa}$ reduced switchgrass photosynthetic rates and xylem pressure potential. As plant spacing increased, tiller number, leaf area, plant dry weight, and morphological development stage increased. Plant dry weight and tiller number in the establishment year was not affected by $\mathrm{N}$ input. Established plants in 1994, however, responded to high $\mathrm{N}$ input at low plant densities with 50 to $100 \%$ greater leaf area and up to 3-fold greater plant dry weight compared to the low-N treatment. The increased plant dry weight at high $N$ input resulted from increased individual tiller weight and not increased tiller number. Our data indicate that competitive responses of switchgrass plants at high plant densities were controlled by competition for aboveground resources, as plant yield and morphology at high densities were not affected by water or $\mathrm{N}$ inputs.
\end{abstract}

Key Words: Panicum virgatum, morphological development, stress

Switchgrass is a warm-season perennial grass commonly grown in the Great Plains for harvested forage and grazing. Recent interest in alternative uses for switchgrass (e.g., biomass energy feedstock; McLaughlin and Walsh 1998) has prompted questions about how resource inputs (such as water and nutrients) affect growth, development, and plant relations of switchgrass. Water

Research supported by the Biofuels Systems Division under contract DECo5-840R21400 to Oak Ridge National Laboratory managed by Lockheed Martin Energy Systems. The authors thank Dr. Stan Wullschleger, Oak Ridge National Laboratory, for advice in conducting this experiment and for the use of the time domain reflectometer.

Manuscript accepted 16 May 1999.

\section{Resumen}

"Switchgrass" (Panicum virgatum L.), un componente importante de las praderas de zacares altos, es un zacate forrajero productivo de estación caliente. El interés de cultivar "Switchgrass" para usos alternativos ha generado preguntas acerca del uso de recursos durante la producción. El objetivo de nuestro estudio fue examinar como la adición de recursos afectó la competencia interespecífica del "Switchgrass". En Mayo de 1993, mediante semilla, se estableció el zacate "Switchgrass" variedad 'Alamo' en lísimetros colocados en el exterior, las plantas se fertilizaron con 22 o $112 \mathrm{~kg} \mathrm{ha}^{-1}$ de nitrógeno y crecieron bajo condiciones de capacidad de campo o déficit de humedad hasta Agosto de 1994. El espaciamiento entre plantas vario sistemáticamente de 10 a $70 \mathrm{~cm}$. Las plantas se cosecharon a fines del verano de cada año y a cada una de ellas se les determino individualmente el peso seco, número de hijuelos, área foliar y desarrollo morfológico. Tensiones de humedad del suelo abajo de a $-45 \mathrm{kPa}$ redujeron las tasas fotosintéticas y el potencial de presión del xilema del "Switchgrass". Conforme el espaciamiento entre plantas aumento, el número de hijuelos, área foliar, peso seco y desarrollo morfológico también aumentaron. Durante el año de establecimiento, la adición de nitrógeno no afecto el peso seco ni número de hijuelos de las plantas. Sin embargo, en 1994, las plantas establecidas a respondieron a la adición alta de nitrógeno; a densidades bajas de plantas, el área foliar aumento de 50 a $100 \%$ y el peso seco por planta hasta en 3 veces comparadas con las plantas con una adición baja de nitrógeno. El aumento del peso seco de las plantas en el tratamiento alto en nitrógeno fue producto de un aumento del peso individual de los hijuelos y no de un incremento en el número de ellos. Nuestros datos indican que la respuesta competitiva de plantas de "Switchgrass" en altas densidades fue controlada por la competencia por los recursos arriba de la superficie del suelo ya que el rendimiento por planta y su morfología a altas densidades no fueron afectados por la adición de nitrógeno o agua.

and nitrogen are the principal resources limiting productivity in perennial warm-season grass ecosystems (Epstein et al. 1996) and efficient use of these inputs in switchgrass production is critical.

Competition between plants is affected by plant population density (nearness and number of neighbors) and resource availability (Murphy and Briske 1992). In grasses, several morphogenetic changes, such as reduced tillering and increased shoot 
height, are presumably mechanisms for individual plants to adapt to resource availability (Ballare et al. 1995). These changes may buffer fluctuations in herbage yield. For example, Sanderson et al. (1996) reported that herbage yield of switchgrass was the same whether grown in rows spaced 10 or $100 \mathrm{~cm}$ apart because of compensatory responses in tiller number and size. At low plant population densities, individual plants may exploit larger pools of resources from above and below ground. If some soil resources are limited, input of additional water or nutrients should compensate for increased plant density.

The objective of our study was to examine how $\mathrm{N}$ and water affected competition among plants in switchgrass. We varied plant density, $\mathrm{N}$ fertility, and water availability and measured tillers and leaf area per plant, individual plant dry weight, and developmental stage to examine effects of these treatments on switchgrass morphology and development.

\section{Materials and Methods}

'Alamo' switchgrass seed was planted in sixteen, $1.8-\mathrm{m}$ diameter by $0.6-\mathrm{m}$ deep lysimeters (galvanized metal tanks) on 4 May 1993 at the Texas A\&M University Agricultural Research and Extension Center at Stephenville, Tex. The lysimeters were outdoors in 2 rows spaced $2 \mathrm{~m}$ apart. The soil in each lysimeter was a Bunyan loam (fine loamy, mixed, nonacid, thermic, Typic Udifluvents). The lysimeters were filled so that the original soil profile and bulk density were maintained as much as possible. A $10-\mathrm{cm}$ layer of pea gravel was placed in the bottom of each lysimeter and a 5-cm outlet was maintained for water drainage. The lysimeters were filled with soil in 1992 and allowed to settle until 1993. Analysis of soil samples taken to $15 \mathrm{~cm}$ in 1993 indicated 3.3 $\mathrm{mg} \mathrm{NO}_{3}-\mathrm{N} \mathrm{kg} \mathrm{kg}^{-1}$ of dry soil, $22 \mathrm{mg}$ extractable $\mathrm{P} \mathrm{kg}^{-1}, 108 \mathrm{mg}$ extractable K $\mathrm{kg}^{-1}$ and a $\mathrm{pH}$ of 8.0.

The planting arrangement in each lysimeter was a systematic design for plant spacing experiments (Nelder 1962). Plots were arranged in a wagon-wheel lay out with 8 radii (spokes) and 4 plants per radius. Each radius was planted along its entire length with switchgrass seeds. Plants were thinned on 8 June 1993 to 1 plant each at 10,20,40, and $70 \mathrm{~cm}$ from the center of the lysimeter. Plants were watered in all lysimeters to ensure establishment.
Treatments applied to the lysimeters included $\mathrm{N}$ fertilizer rates at 22 or $112 \mathrm{~kg}$ $\mathrm{N} \mathrm{ha}^{-1}$ (as ammonium nitrate, no other fertilizer was applied) and soil water levels of approximately field capacity and $50 \%$ water deficit. The $\mathrm{N}$ fertilizer was applied in July of 1993 after seedlings had established (tillers had formed on the main stem), and in April of 1994. Beginning 7 July 1993, the water levels were imposed and maintained by an automated watering system controlled by tensiometers (Soil Moisture Equipment model 2725, Santa Barbara, Calif.) placed $30 \mathrm{~cm}$ deep in each lysimeter. The tensiometers had a magnetic switch that triggered a solenoid valve when soil water tension fell below a preset level of $-10 \mathrm{kPa}$ for the field capacity treatment and $-50 \mathrm{kPa}$ for the water deficit treatment. A timing device was programmed to query the solenoid valves at 0800,1200 , and 1700 hours each day. If the solenoid was switched on, water was applied for 1 hour. Water was distributed within the lysimeter via a drip irrigation system with 9 emitters spaced $10 \mathrm{~cm}$ apart and arranged in a circle. The experimental design was a randomized complete block with a 2 x 2 factorial arrangement of $\mathrm{N}$ and water levels in 4 blocks.

Photosynthetic rates were measured periodically to determine if treatments affected plant physiological functions. Photosynthetic rate of the most recent fully expanded leaf blade on 2 tillers from 2 plants at the $40-\mathrm{cm}$ spacing in each lysimeter was measured on 7 dates in 1993 and 6 dates in 1994 with a Li-Cor 6200 portable photosynthesis system (Li-Cor Inc., Lincoln, Neb.). Preliminary measurements showed that plant density did not affect photosynthetic rates. Measurements were made during 1000 to 1400 hours on clear days. Only leaves in the fully exposed upper portion of the plant were measured. Leaves used for photosynthesis measurements were also used for xylem pressure potential measurements immediately after with a leaf pressure chamber (Scholander et al. 1965). In 1994, volumetric soil water content to a $30-\mathrm{cm}$ depth was estimated with a calibrated time domain reflectometer (Trase System I, Soil Moisture Equipment Co., Santa Barabara, Calif.) on the days when photosynthesis measurements were made.

Plant height, tiller number per plant, and stage of morphological development (Sanderson, 1992) were measured weekly on each plant at each density on 4 radii beginning 28 June 1993 and 18 April 1994 and continuing until 1 September 1993 and 15 August 1994. On 9 September
1993 and 20 August 1994, plants in 4 radii from each lysimeter were harvested by hand to a $15-\mathrm{cm}$ stubble. Tiller number per plant, morphological development stage of 5 tillers per plant, height of the 2 tallest tillers, and leaf blade area and dry weight ( 2 radii only) of each plant were measured. Plant and leaf blade dry weight were determined by drying at $55^{\circ} \mathrm{C}$ for 48 hours. Total Kjeldahl $\mathrm{N}$ was determined on leaf blades of plants in 1 radius from each lysimeter in 1993 and 1994. In August 1994, root mass was determined in each lysimeter by taking five, $7.5-\mathrm{cm}$ diameter by $60-\mathrm{cm}$ deep soil cores and washing roots from the soil over a $0.5 \mathrm{~mm}$ sieve. Roots were dried at $55^{\circ} \mathrm{C}$ for 72 hours to determine dry weight. In 1994, the plant crowns (stubble and plant material to a $5-\mathrm{cm}$ depth) were dug from the soil and the total number of visible buds (crown and rhizome buds) were counted.

The data were analyzed as a 2 × 2 factorial with 4 replicates. Responses to plant spacing were determined by linear regression and a comparison of regression slopes and intercepts of each treatment (SAS 1988).

\section{Results and Discussion}

\section{Soil Water Levels in Lysimeters and Plant Physiological Function}

During 1993, soil water tension was relatively constant in lysimeters used for the field capacity treatment (Fig. 1). The water-deficit treatment developed soil water deficits during 15 July to 13 August, 19 to 23 August, and 27 August to 1 September. In each instance (except for 12 August) the water deficit was relieved by natural rainfall. All lysimeters were rewatered to field capacity on 12 August to start a second wet-dry cycle.

During 1994, there were 4 periods of low soil water in the water-deficit treatment: 20 May to 6 June; 21 June to 1 July; 11 to 23 July; and 26 July to 8 August (Fig. 1). The high-N, water-deficit treatment developed a lower soil water tension in the upper $30 \mathrm{~cm}$ of soil than did the low-N field-capacity treatment probably because there was a greater amount of transpiring biomass in the high $\mathrm{N}$ treatment. Despite irrigation, the field-capacity treatment developed relatively low soil moisture tensions during 27 May to 1 June, 1 July to 5 July, and 6 July to 11 July. Measurements of volumetric soil water content at 5 dates in 1994 confirmed the soil water tensions measured by tensiometer (Table 1). Rainfall was much less 


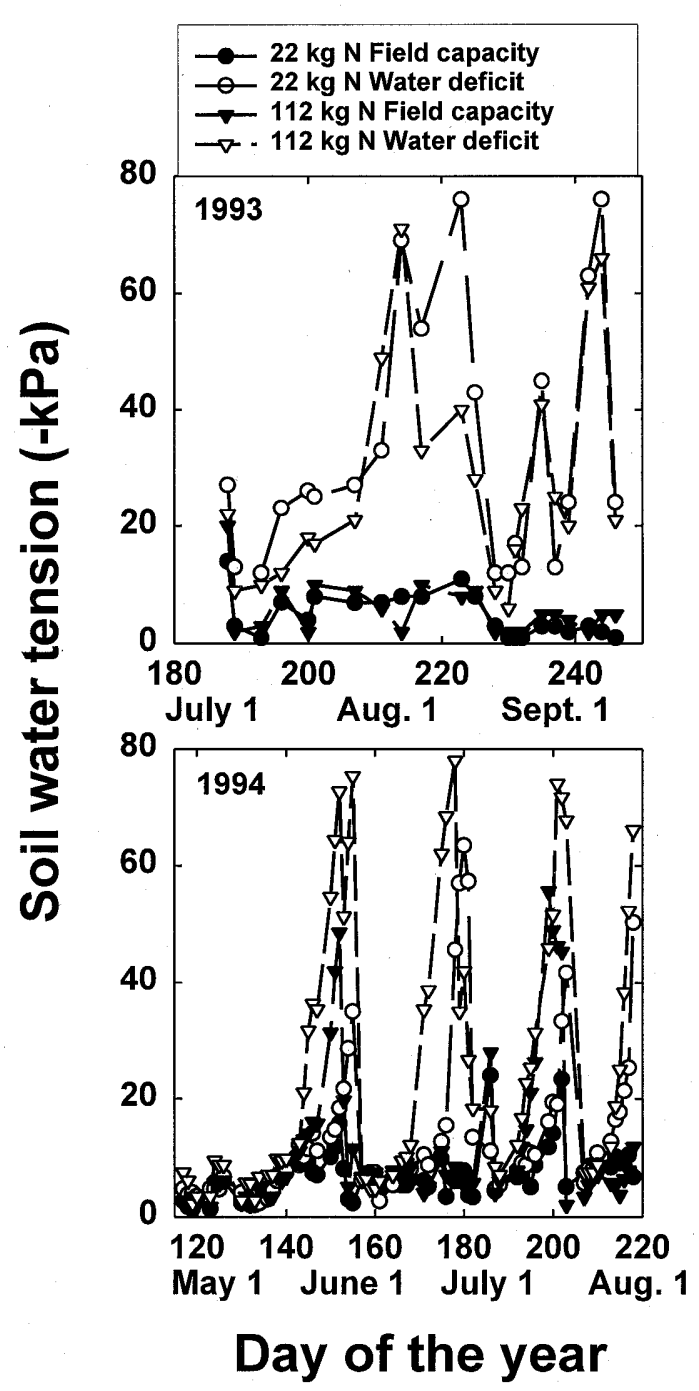

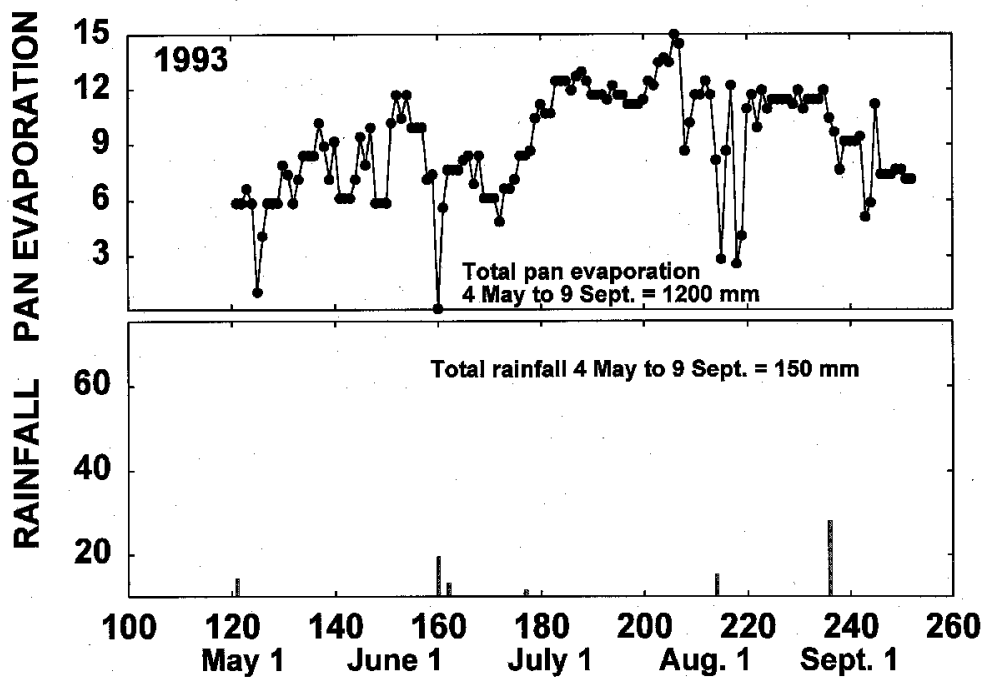

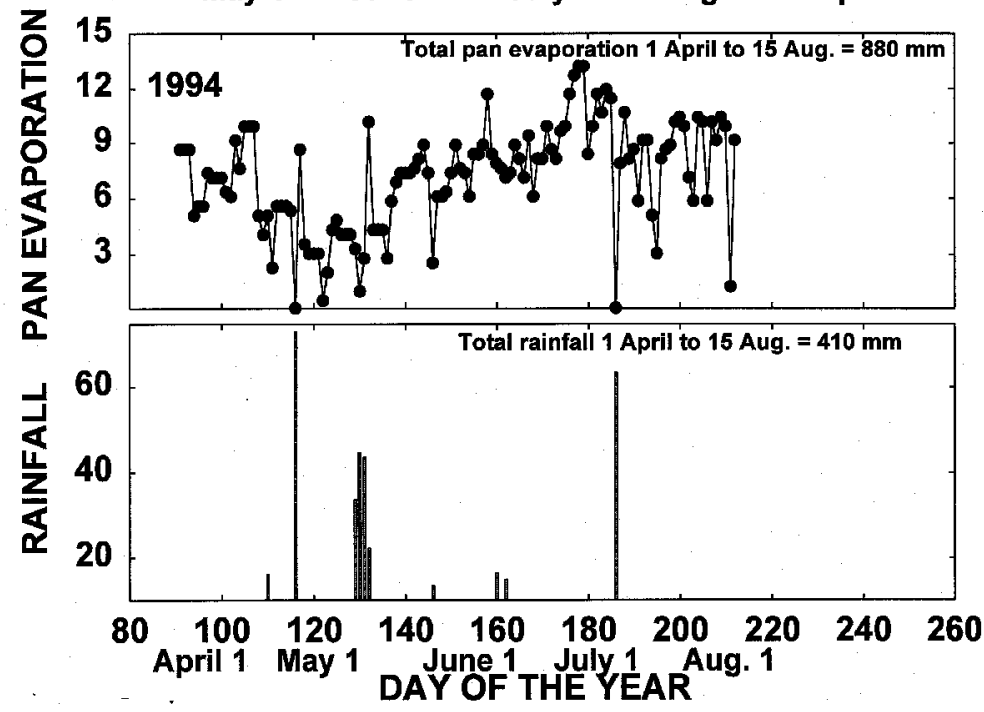

Fig. 1. Soil water tension (-kPa) as indicated by tensiome- Fig. 2. Daily open pan evaporation and rainfall (mm) during 4 May ters placed 30-cm deep in the soil of each lysimeter. Data points are averages of 4 replicate lysimeters.

(planting) to 9 September (harvest), 1993 and 1 April (greenup) to 20 August (harvest) 1994. and pan evaporation was greater during the 1993 growing season compared to 1994 (Fig. 2).

We tried to time photosynthesis measurements to coincide with periods of water deficit to document effects on physiological function; however, because of limited time and climatic conditions (measurements were made between 1000 and 1400 hours on clear days), we were able to document water-deficit effects on photosynthetic rates only on 12 and 30 August in 1993 and 29 June, 22 July, and 10 August in 1994. Switchgrass maintained relatively high rates of photosynthesis on 17 and 26 July 1993, which were not affected by $\mathrm{N}$ or water level (Table 1) and were similar to rates reported by Wullschleger et al.
(1996) for Alamo switchgrass grown in the field.

On 12 August 1993, after water was withheld for 15 days, photosynthetic rate of plants in the water-deficit treatment was only $10 \%$ of that for plants in the fieldcapacity treatment, whereas xylem pressure potentials dropped from about -1.6 to -3.3 $\mathrm{MPa}$. When all lysimeters were rewatered and plants allowed to recover until 20 August, photosynthetic rates and xylem pressure potential recovered to pre-stress levels. On 24 and 27 August, time and atmospheric conditions allowed us to obtain measurements only from the waterdeficit treatments. Photosynthetic rates were lower on these dates than on 20 August, indicating a developing water deficit. On 30 August, it appeared that water deficit significantly reduced photosynthetic rates and xylem pressure potential compared to the field-capacity treatment.

In 1994, photosynthetic rates and xylem pressure potential were reduced in waterdeficit treatments on 29 June, 22 July, and 10 August. On 22 July, only the high-N water-deficit treatment had significantly lower photosynthetic rates and xylem pressure potential than other treatments, whereas on 29 June and 10 August, both low- and high-N water-deficit treatments had lower photosynthetic rates and xylem pressure potential. Rainfall was abundant during April and May (Fig. 2) and precluded the development of significant soil water deficits in the spring. 
Table 1. Photosynthetic rates, xylem pressure potential, and soil moisture in each treatment on several dates in 1993 and 1994

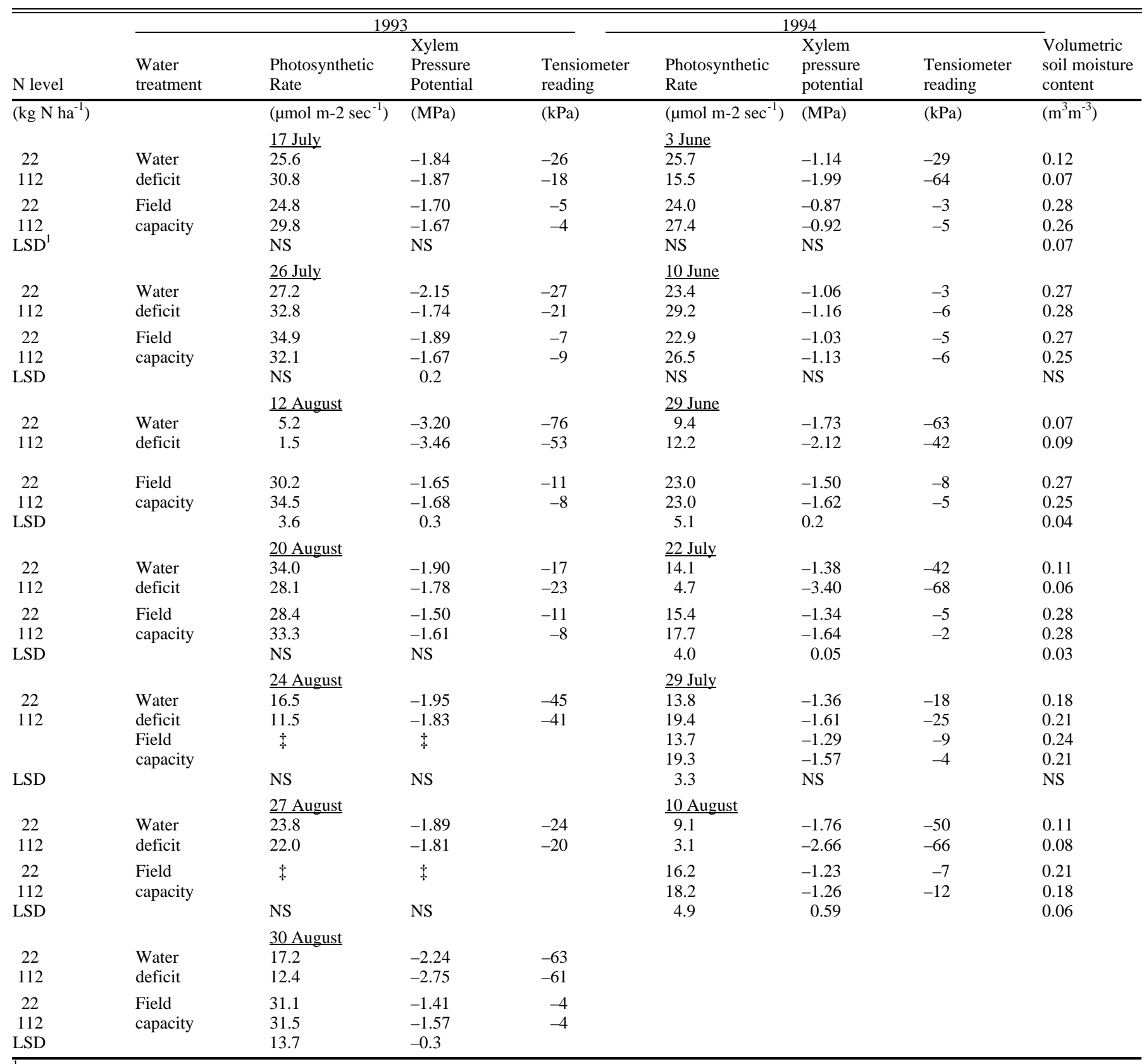

${ }^{1} \mathrm{LSD}=$ least significant difference at $\mathrm{P}<0.05$. $\ddagger$ Data were not taken.

Although we were not able to measure photosynthetic rates as often as we would have liked, it was clear that the waterdeficit and field-capacity treatments differed in soil water levels and that these differences affected physiological function of switchgrass. When soil water tension was less than about $-45 \mathrm{kPa}$, xylem pressure potential and photosynthetic rates were severely reduced indicating significant plant stress. Knapp (1985) reported photosynthesis rates near zero for switchgrass plants under severe water deficit (xylem pressure potential $<-2.0 \mathrm{MPa}$ ) on the Konza prairie in Kansas.

\section{Plant Dry Weight}

In 1993, the dry weight of individual switchgrass plants was not affected $(\mathrm{P}<$ 0.05 ) by water or $\mathrm{N}$ inputs. Plant spacing had the largest effect on plant dry weight and all treatments increased linearly in weight with increased plant spacing (Fig. 3). During 1994, however, switchgrass plants responded strongly to increased $\mathrm{N}$ fertilizer, but not to additional water. Switchgrass plants increased in dry weight with increased plant spacing, but the response (slope of the regression line) was nearly doubled with increased $\mathrm{N}$ fertilizer.
Thus, neither increased water nor $\mathrm{N}$ fertilizer were able to overcome the aboveground competition among plants at the higher plant densities.

The absence of a response in dry weight of seeding year switchgrass plants to or $\mathrm{N}$ input may indicate that the soil pool of $\mathrm{N}$ was adequate and that the young plants were able to explore and exploit a large volume of soil. In 1994, plants probably had a fully developed root system, which was able to draw more resources. Root dry weight was significantly higher for the $112 \mathrm{~kg} \mathrm{~N}$ treatment than in the low-N 


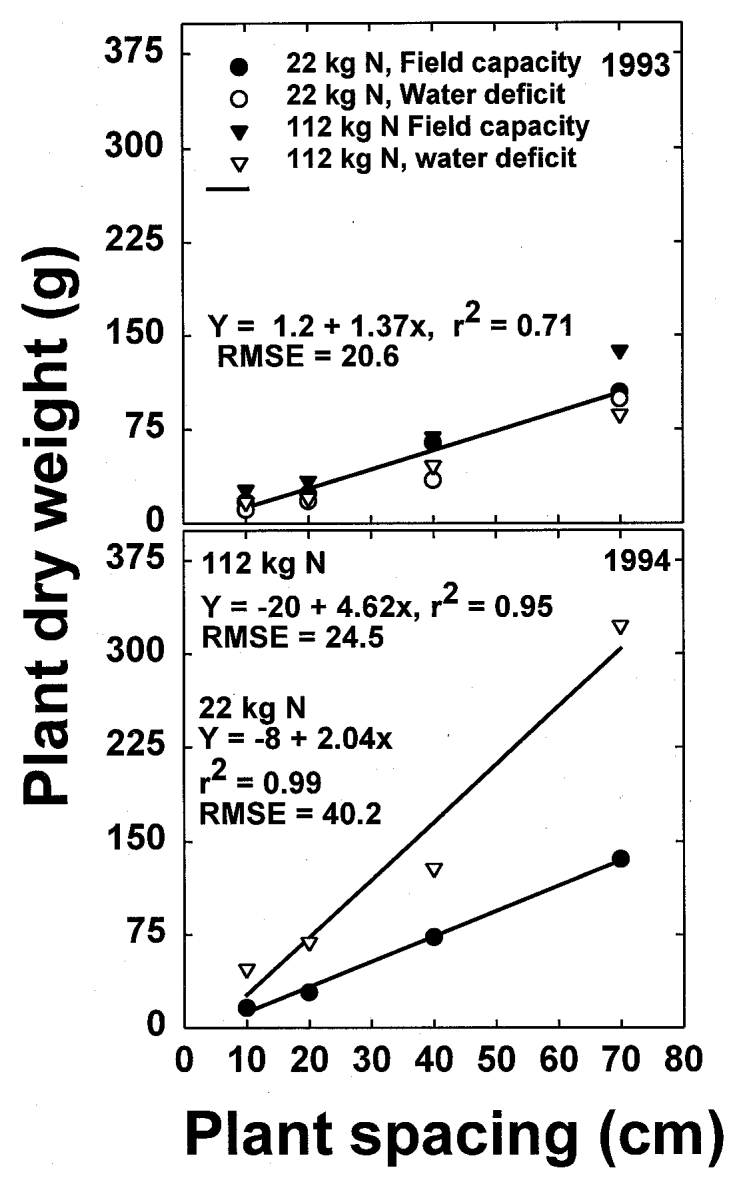

Fig. 3. Yield of dry matter per plant at $2 \mathrm{~N}$ and water levels in response to plant spacing. Data points in 1994 are the averages of 2 water treatments for each $\mathbf{N}$ level. RMSE = root mean square error.

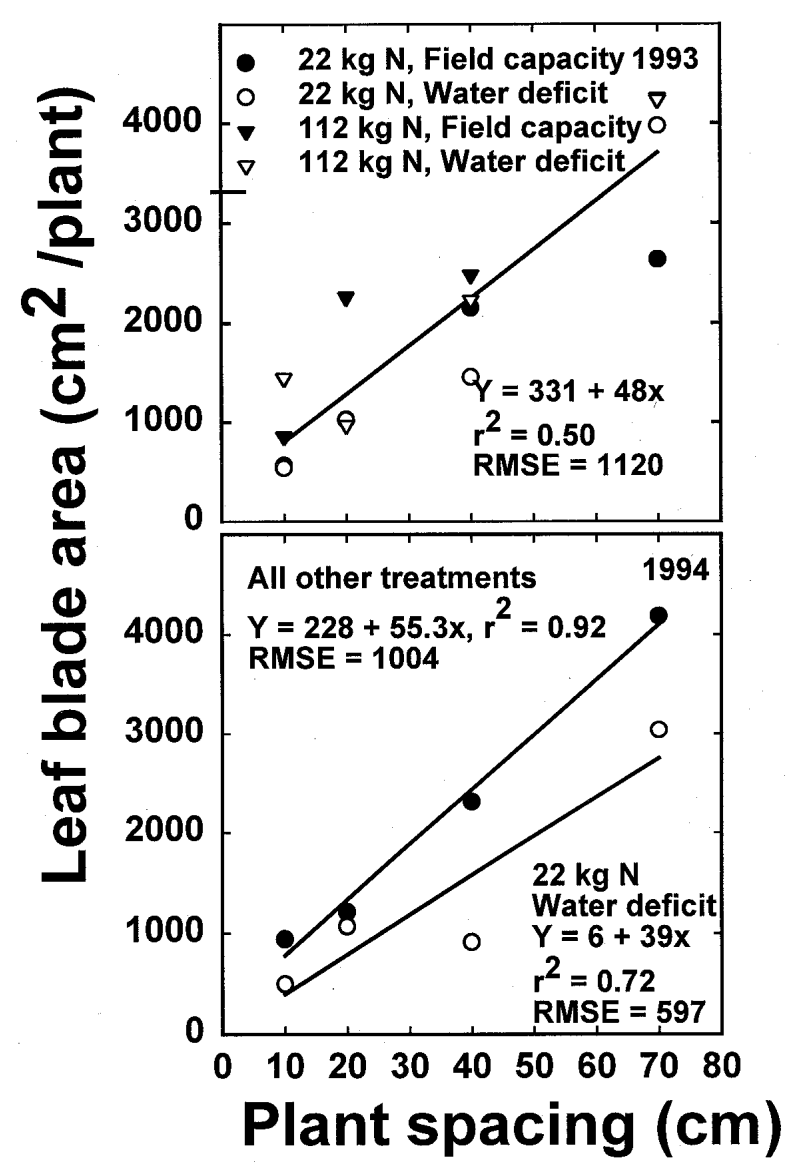

Fig. 4. Leaf blade area per plant at $2 \mathrm{~N}$ and water levels in response to plant spacing. There was no significant difference among the water treatments at $112 \mathrm{~kg} \mathrm{~N}$ and the $22 \mathrm{~kg} \mathrm{~N}$ field capacity water treatment, thus, these data were averaged for the regression response line. RMSE = root mean square error. treatment at the end of the season in 1994 , but was not affected by water level (Table 2). In 1993, all treatments were watered until 7 July to assure establishment. Significantly lower soil moisture tensions occurred after this, but all treatments were watered again on 12 August. Thus despite documenting significant differences in photosynthetic rates between water treatments on some dates (Table 1), the water deficit periods may not have been long enough to significantly reduce plant yields. Lower yields in 1993 compared to 1994 were a result of slow seedling growth and a shorter growing season (May to August in 1993 and March to September in 1994).

Leaf area per plant increased linearly with increasing plant spacing in 1993, but there were no significant differences among $\mathrm{N}$ or water treatments (Fig. 4). During 1994 , the leaf area of plants grown with low $\mathrm{N}$ and under water deficit responded less (smaller regression slope) to wider

Table 2. Dry weight of switchgrass roots to a 60-cm depth in August 1994 as affected by nitrogen rate and soil water level.

\begin{tabular}{|c|c|c|c|}
\hline \multirow[b]{2}{*}{ Water treatment } & \multicolumn{2}{|c|}{ Nitrogen level $\left(\mathrm{kg} \mathrm{ha}^{-1}\right)$} & \multirow[b]{2}{*}{ Mean } \\
\hline & 22 & 112 & \\
\hline & \multicolumn{3}{|c|}{ - } \\
\hline Field capacity & 11700 & 15300 & 13500 \\
\hline Water deficit & 9900 & 13500 & 11700 \\
\hline $\operatorname{Mean}^{1}$ & $11000 \mathrm{a}$ & $14400 \mathrm{~b}$ & \\
\hline SEM & \multicolumn{2}{|c|}{1200} & \\
\hline
\end{tabular}

${ }^{1}$ Means are significantly different at $\mathrm{P}<0.05$. plant spacing than the other treatments, which were not significantly different.

Leaf $\mathrm{N}$ concentration varied among years and treatments (Table 3). In 1993, plants grown with high $\mathrm{N}$ and under water deficit had one-third greater $\mathrm{N}$ concentration than other treatments. In 1994, there was no effect of water deficit, but the 112$\mathrm{kg} \mathrm{N}$ treatment had $36 \%$ greater leaf $\mathrm{N}$ than the 22-kg N treatment. There was an interaction among $\mathrm{N}$ and water treatments in leaf $\mathrm{N}$ concentration. Leaf $\mathrm{N}$ was not different between water treatments at the 22-kg N treatment, whereas leaf $\mathrm{N}$ increased with water deficit in the $112-\mathrm{kg}$ $\mathrm{N}$ treatment.

\section{Tiller Dynamics}

Tiller number per plant increased linearly with increasing plant spacing and was not affected by $\mathrm{N}$ or water inputs in either year (Fig. 5). Thus, differences in yield per plant among treatments in 1994 probably resulted from increased tiller size rather than tiller number. Moreover, tiller 


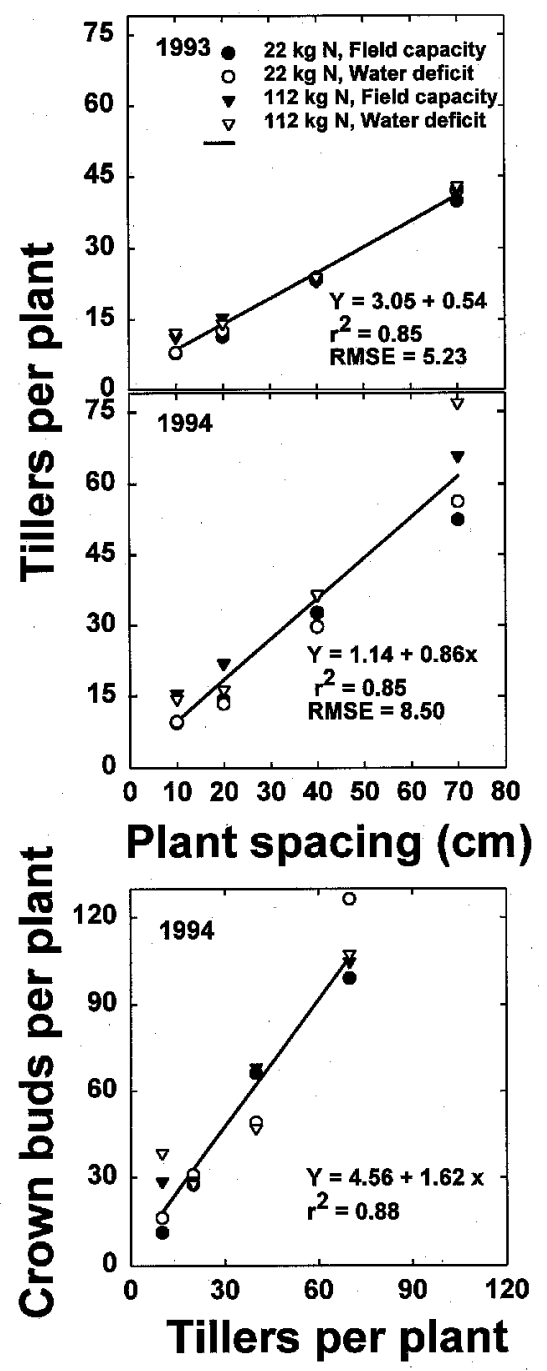

Fig. 5. Number of tillers per plant at $2 \mathrm{~N}$ and water levels in response to plant spacing in 1993 and 1994, and number of visible buds on the plant crown after harvest in 1994. RMSE = root mean square error.

number seemed to be affected more by aboveground competition than by competition for belowground resources. Similar to tiller number, the number of visible buds on the plant crown after harvest in 1994 increased linearly with increasing plant spacing and was not affected by $\mathrm{N}$ or water inputs (Fig. 5).

The pattern of tillering during the 1993 season was different among plant spacings (Fig. 6). Plants at the 40 and $70 \mathrm{~cm} \mathrm{spac-}$ ings increased greatly in tiller number from July to September. At the 2 lower plant spacings, there was a small increase in tiller number during June, but tiller number remained relatively constant after that. Peak tiller recruitment occurred during early May and early July for plants at the 40 and $70 \mathrm{~cm}$ spacings in 1994 . At the 10

Table 3. Concentration of $\mathrm{N}$ in leaf blades of switchgrass in 1993 and 1994 as affected by nitrogen rate and soil water level.

\begin{tabular}{|c|c|c|c|}
\hline \multirow[b]{2}{*}{ Water treatment } & \multicolumn{2}{|c|}{ Nitrogen level $\left(\mathrm{kg} \mathrm{ha}^{-1}\right)$} & \multirow[b]{2}{*}{ Mean } \\
\hline & 22 & 112 & \\
\hline \multicolumn{4}{|c|}{ - } \\
\hline & & 1993 & \\
\hline Field capacity & 8.2 & 10.8 & $9.5 \mathrm{a}$ \\
\hline Water deficit & 11.3 & 15.1 & $13.2 \mathrm{~b}$ \\
\hline Mean $^{1}$ & $9.8 \mathrm{a}$ & $13.0 \mathrm{~b}$ & \\
\hline \multirow[t]{2}{*}{ SEM } & & 1.11 & \\
\hline & & 1994 & \\
\hline Field capacity & $5.8 \mathrm{a}$ & $7.1 \mathrm{~b}$ & 6.4 \\
\hline Water deficit & $5.5 \mathrm{a}$ & $8.0 \mathrm{c}$ & 6.8 \\
\hline Mean & $5.6 \mathrm{a}$ & $7.6 \mathrm{~b}$ & \\
\hline SEM & & 0.81 & \\
\hline
\end{tabular}

${ }^{1}$ Means are significantly different at $\mathrm{P}<0.05$.

and $20 \mathrm{~cm}$ spacings, there was no spring peak in tiller number, but there was a pronounced increase in tiller number in July. The increase in tiller number during May at the 40 and $70 \mathrm{~cm}$ spacings could have been from rhizomes and crown buds formed during the previous fall, whereas the increase in July may have been from axillary buds. Thus, at all plant spacings, switchgrass was able to initiate and maintain tillers until August, after which tiller mortality increased. Late-formed tillers may not have been able to develop functional roots. When new tillers form, they obtain water via the parent plant until they develop functional adventitious roots (Carman and Briske, 1982). If the root system does not develop, the tillers will die.

\section{Morphological \\ Development}

Developmental stage of switchgrass plants increased with increasing plant spacing in 1993 (Fig. 7). Water deficit retarded morphological development, whereas $\mathrm{N}$ treatment had no effect. Plants in the water-deficit treatment had delayed inflorescence emergence and reproductive development compared with the field-capacity treatment (Fig. 8). In 1994, developmental stage responses to plant spacing dif- fered between $\mathrm{N}$ treatments, but was not affected by water treatments (Fig. 7). Switchgrass plants had a lower developmental stage in the $22-\mathrm{kg} \mathrm{N}$ treatment compared with $112 \mathrm{~kg} \mathrm{~N}$ at the 10 - and $20-\mathrm{cm}$ spacings. There were no differences among treatments at the 40 and 70$\mathrm{cm}$ spacing. Plants in the high $\mathrm{N}$ treatment exerted inflorescences earlier than low-N plants in 1994 (Fig. 8).

The pattern of morphological development in this experiment was similar to that reported by Sanderson (1992) and Sanderson and Wolf (1995). Nitrogen addition to individual switchgrass plants on the Konza Prairie increased the number of tillers that flowered and produced seed (Hartnett 1993) and increased plant density (in a pot experiment in the greenhouse)

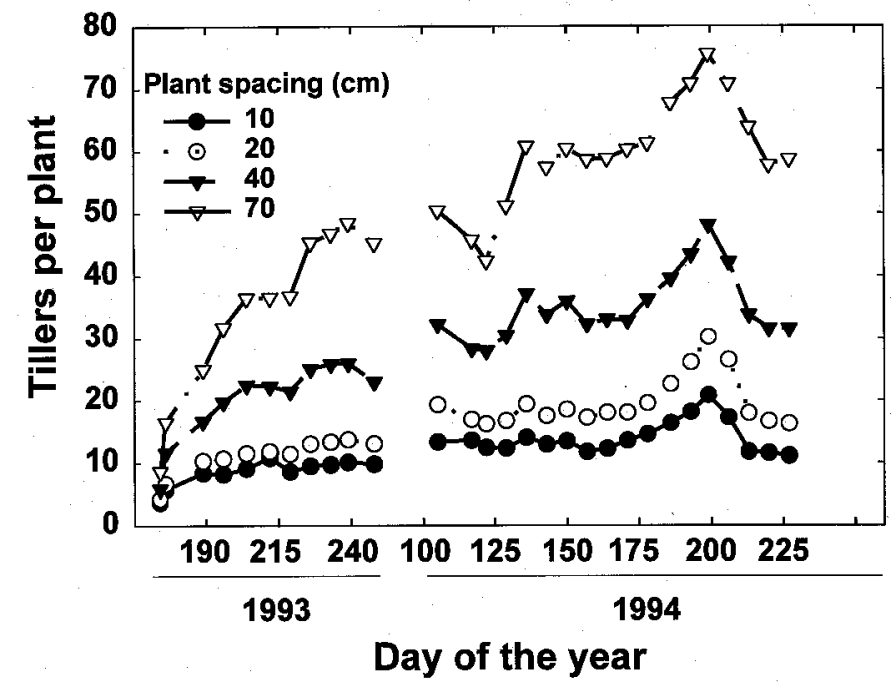

Fig. 6. Tillering patterns of switchgrass from planting to harvest in 1993, and from 15 April to 15 August 1994. Data points are averages of $2 \mathrm{~N}$ and water levels and 4 replicates. 


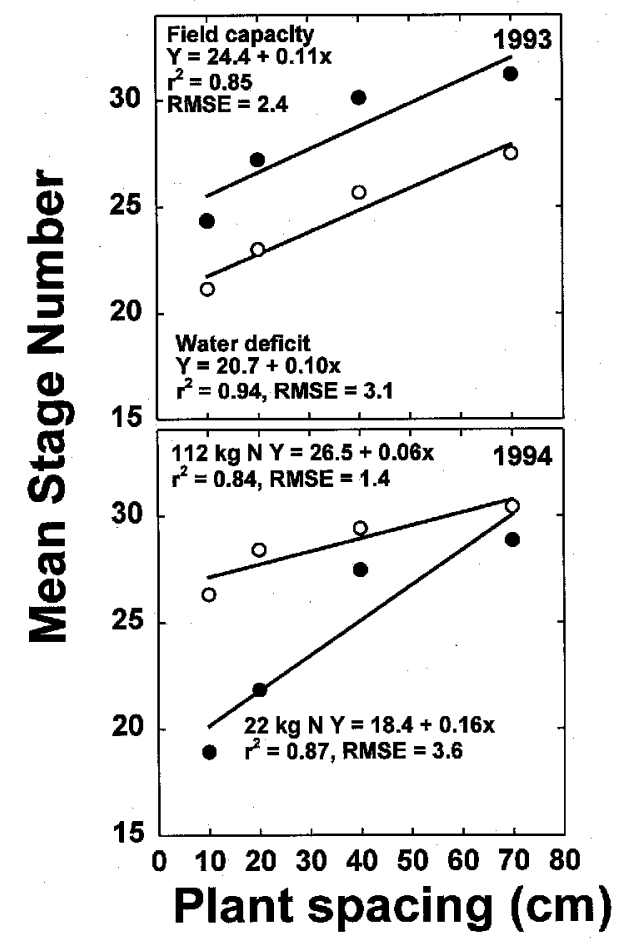

Fig. 7. Mean stage of morphological development at harvest at $2 \mathrm{~N}$ and water levels in response to plant spacing. In 1993, the data points are averages of $2 \mathrm{~N}$ levels, whereas in 1994 the data points are averages of 2 water treatments. Stage number $15=$ vegetative plants with 5 elongated internodes; $20=$ boot stage; $25=50 \%$ of the inflorescence emerged; $30=$ anthesis. Morphological stages determined according to Sanderson (1992).

reduced reproductive growth of switchgrass (Hartnett 1989). Sanderson (1992) and Sanderson and Wolf (1995) reported no differences between wet and dry years in switchgrass development patterns. Thus, switchgrass development may be more sensitive to water stress during the seeding year than in subsequent production years after the plants have fully established.

Our data support the suggestion of Hartnett (1993) that $\mathrm{N}$ availability does not affect the rate of increase in clonal growth of switchgrass. Water availability and the canopy light environment of individual switchgrass plants were shown to be the dominant controls of individual plant tiller growth and dynamics (Hartnett, 1993). Our data were not clear-cut regarding the effects of water availability. We found that water and $\mathrm{N}$ affected tiller size, whereas tiller number was influenced mainly by interplant competition for aboveground resources.

This concept has practical application in managing stands of switchgrass that have

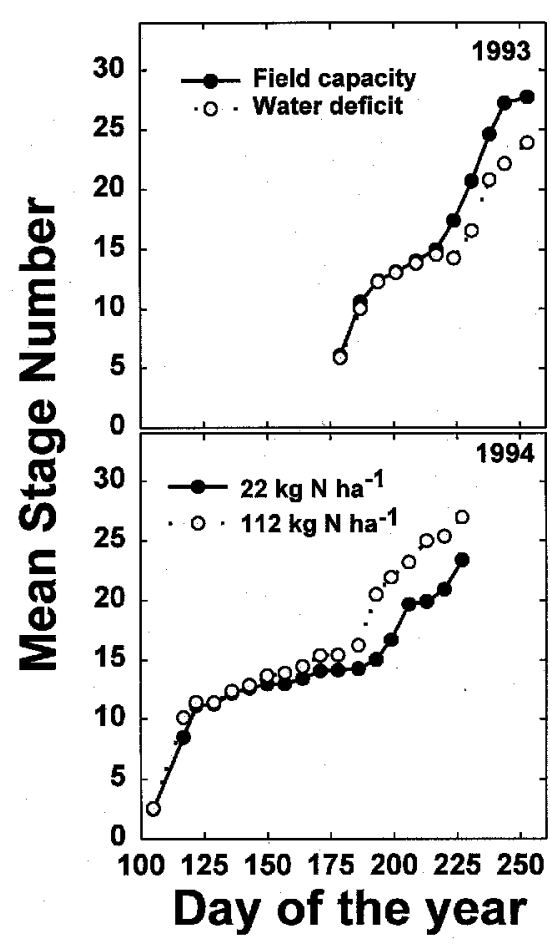

Fig. 8. Morphological development (mean stage number) pattern of switchgrass as affected by soil water level in 1993 and $\mathbf{N}$ fertility in 1994. Stage number $5=$ vegetative plants with 5 fully expanded leave blades and no elongated internodes; $10=$ beginning of internode elongation; 15 $=$ vegetative plants with 5 elongated internodes; 20 = boot stage; $25=\mathbf{5 0 \%}$ of the inflorescence emerged; $30=$ anthesis. Morphological stages determined according to Sanderson (1992).

decreased in density by natural thinning or mismanagement. If stands have thinned to a point at which individual plants are not able to compensate by increased tillering, production cannot be increased from these stands by adding more water or $\mathrm{N}$ fertilizer.

\section{Literature Cited}

Ballare, C.L., A.L. Scopel, and R.A. Sanchez. 1995. Plant morphogenesis in canopies, crop growth, and yield. Hort Sci. 30:11721181.

Carman, J.G. and D.D. Briske. 1982. Root initiation and leaf elongation of dependent little bluestem tillers following defoliation. Agron. J. 74:432-435.

Epstein, H.E., W.K. Lauenroth, I.C. Burke, and D.P. Coffin. 1996. Ecological responses of dominant grasses along two climatic gradients in the Great Plains of the United States. J. Veg. Sci. 7:777-788.

Hartnett, D.C. 1989. Density and growth-stage dependent responses to defoliation in two rhizomatous grasses. Oecologia 80: 414-420.

Hartnett, D.C. 1993. Regulation of clonal growth and dynamics of Panicum virgatum (Poaceae) in tallgrass prairie: Effects of neighbor removal and nutrient addition. Amer. J. Bot. 80:1114-1120.

Knapp, A.K. 1985. Effect of fire and drought on the ecophysiology of Andropogon ger ardii and Panicum virgatum in a tallgrass prairie. Ecol. 66:1309-1320.

McLaughlin, S.B. and M.E. Walsh. 1998. Evaluating environmental consequences of producing herbaceous crops for bioenergy. Biomass and Bioenergy 14:317-324.

Murphy, J.S. and D.D. Briske. 1992. Regulation of tillering by apical dominance: chronology, interpretive value, and current perspectives. J. Range. Manage. 45:419-429.

Nelder, J.A. 1962. New kinds of systematic designs for spacing experiments. Biometrics 18:283-307.

Sanderson, M.A. 1992. Morphological development of switchgrass and kleingrass. Agron. J. 84:415-419.

Sanderson, M.A. and D.D. Wolf. 1995. Morphological development of switchgrass in diverse environments. Agron J. 87:908-915.

Sanderson, M.A., R.L. Reed, S.B. McLaughlin, S.D. Wullschleger, B.V. Conger, D.J. Parrish, D.D. Wolf, C. Taliaferro, A.A. Hopkins, W.R. Ocumpaugh, M.A. Hussey, J.C. Read, and C.R. Tischler. 1996. Switchgrass as a sustainable bioenergy crop. Bioresource Tech. 56:83093.

SAS 1988. SAS Institute Inc. SAS/STAT User's Guide, Release 6.03. SAS, Cary, N.C.

Scholander, P.F., H.T. Hammel, E.D. Bradstreet, and E.A. Hemmingsen. 1965. Sap pressure in vascular plants. Sci. (Wash. D.C.) $148: 339-346$.

Wullschleger, S.D., M.A. Sanderson, S.B. McLaughlin, D.P. Bindar, and A.L. Rayburn. 1996. Photosynthetic rates and ploidy levels among populations of switchgrass. Crop Sci. 36:306-312. 